\section{ECONOMICS}

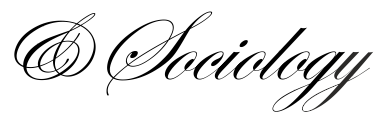

Rahmatiah, Wiroto, D. W., \& Taan, H. (2019). Business continuity, motivation, and social conditions of young entrepreneurs. Economics and Sociology, 12(4), 166182. doi:10.14254/2071- 789X.2019/12-4/10

\title{
BUSINESS CONTINUITY, MOTIVATION, AND SOCIAL CONDITIONS OF YOUNG ENTREPRENEURS
}

\author{
Rahmatiah, \\ Department of Sociology, Faculty of \\ Social Science, Universitas Negeri \\ Gorontalo, Indonesia \\ E-mail: rahmatiab@ung.ac.id
}

\section{Dondick W. Wiroto,}

Department of Sociology, Faculty of Social Science, Universitas Negeri

Gorontalo, Indonesia

E-mail:dondickwiroto@ung.ac.id

\author{
Hapsawati Taan, \\ Department of Marketing \\ Management, Faculty of \\ Economics, Universitas Negeri \\ Gorontalo, Indonesia \\ E-mail: hapsawatitaan@ung.ac.id
}

Received: December, 2018

1st Revision: September, 2019

Accepted: December, 2019

DOI: $10.14254 / 2071-$

789X.2019/12-4/10

JEL Classification: L26, M13
ABSTRACT. The insignificant amount of Indonesian youths engaging in entrepreneurship has led to the assumption that it is difficult for youths to become entrepreneurs for their lack of capacity to create and innovate, and also their lack of courage to take risks. As a result, there is nearly no study on the capacity of young Indonesian entrepreneurs in maintaining their business continuity. This qualitative research, thus, aims to explore - by using the narrative method - the experiences of six young entrepreneurs in Indonesia when they were in a condition to decide to become an entrepreneur, and the conditions of running a business, with the purpose of understanding the context in which the youths opt to maintain business continuity. The study results indicate that despite being committed to themselves, their businesses, and their social capital, the youths' motivation to maintain their business continuity varies. More dynamic social conditions and more social relations result in more successful business continuity for it is driven by more superior motivation of young entrepreneurs; conversely, if social conditions are merely formed by internal conditions and fewer social relations, then youths' motivation to continue their business is low.

Keywords: young entrepreneurs, business continuity, commitment, motivation, morphogenetic, social conditions, Indonesia 


\section{Introduction. The search for a sociological explanation on youths' business continuity}

This is a socioeconomic research on youth entrepreneurship. Entrepreneurial patterns in business continuity generally do not receive much attention in sociology. Actions taken by entrepreneurs are substantial in order for their businesses to keep operating and expanding (establishing, maintaining, and developing business), which we often find in management literature as standalone phenomena, while in fact they may essentially be found through sociological approaches, namely Margaret Archer's theory of morphogenesis. Margaret Archer's morphogenetic perspective emphasizes that actors have their respective life history (social relation-entrepreneur's culture) indicating numerous changes (ideas, beliefs, values, and actions of entrepreneurs) that are beneficial in empowering and restraining them when they design their projects (including entrepreneurship) (Mole \& Mole, 2010).

Youths and other generations in the society undergo intense modernization processes that are full of uncertainties (Furlong \& Cartmel, 2007). Lewin (2012) mentions that uncertainty is a situation that makes entrepreneurship possible, yet the capability of utilizing such uncertain conditions can only be specified as a capability possessed by stable MSMEs (capable of maintaining their competitive and comparative advantage), but not by newly established MSMEs (Wiroto, 2016). Unstable micro and small enterprise conditions would instead compel youths to confront uncertain conditions and become potential job-seekers or entrepreneurs (Rahmatiah, Wiroto \& Taan, 2017).

Our prior study on several successful young entrepreneurs in Indonesia (Rahmatiah, Wiroto, dan Taan, 2017) found that they possess a number of ideal sociological factors that we call the "four dimensions of young entrepreneur's identity", which are: experienced a triggering incident that drove them to become entrepreneurs; create business plans and constantly improve them; create various innovations; and have clear business implementation plan. Our prior research found that not all young entrepreneurs in Indonesia possess these four dimensions of young entrepreneur's identity as ideal sociological factors, even more so with the factors of business planning and entrepreneurship implementation. We have, subsequently, focus our further research on understanding the processes undertaken by young entrepreneurs in Gorontalo Municipality in order to survive and develop as entrepreneurs despite missing some of the four dimensions of young entrepreneur's identity.

Stemming from such a focus of this follow-up study and the morphogenetic approach, the aim of this research is to gain an understanding on the processes that the youth carried out to maintain own business continuity. Several hypotheses were made basing on the results of our previous research. These hypotheses are:

1. Continuity of youth's business is determined by their ability to deal with various conditions when deciding to become an entrepreneur and conducting business processes. $(\mathrm{H}-1)$

2. Youth's ability to deal with various conditions when deciding to become an entrepreneur is determined by their ability to make use of their social relationship background and their business knowledge for starting a business. (H-2)

3. Youth's ability to deal with various conditions when conducting business processes is determined by their ability to constantly gain profit and apply entrepreneurial principles and values in the businesses they own $(H-3)$.

The discussion and results of this qualitative study show that our hypotheses are validated, they were even further developed, among others, due to the use of sociological concepts of business continuity and research findings resulting in other sociological concepts that are relevant to business continuity such as commitment, motivation, and social conditions. 


\section{Sociological approach in issues of business continuity}

In reality, although under significant conditions of uncertainty, there are still young people opting to become entrepreneurs. The dilemma young people face in choosing to become a potential job-seeker or entrepreneur classifies young entrepreneurs into two categories: those driven by the necessity to become an entrepreneur (necessity entrepreneurship); and those driven by the opportunity to become an entrepreneur (opportunity entrepreneurship) (Lippman, Davis, \& Aldrich, 2005; Williams \& Nadin, 2010). Opportunity entrepreneurship shows a more advanced endeavor than necessity entrepreneurship because the latter describes a person who becomes an entrepreneur due to structural circumstances, namely having to survive and being less fortunate in finding decent employment opportunities (Williams \& Gurtoo, 2012) and for lack of any other choices than maintaining business operation (Grilli, 2010). Unfortunately, this division is unable to show which of the two is better in maintaining business continuity. According to Max Weber, the entrepreneur principle is to control and calculate with maximum efficiency the entire means of production under a general management (Collins, 1980). Basically, young entrepreneurs should bear characters of modern capitalist entrepreneurs, particularly in gathering and optimizing organizational assets in order to avoid business failure (Bennet, 2016).

Successful entrepreneurship may be understood in three ideal conditions of entrepreneur, namely: the transition to entrepreneurship, followed by the entrepreneurship process, and ultimately the entrepreneurship structure. At the micro scale, individuals transition into entrepreneurs because of their interactions with their external environments (individual interactions with their interpersonal networks) allowing them to gain resources and information derived from their social capital. Subsequently, the individual digs into their internal capability to change these resources into financial capital and information into human capital/motivation for themselves to become an entrepreneur. The entrepreneur process enables them to gain benefit and establish entrepreneur identity upon themselves. Ultimately, an entrepreneurship micro structure (the individual's identity as an entrepreneur with more expansive interpersonal networks) is created, that is the availability of social capital that relates to business activities requiring expenditures, and social capital beneficial to create the public's trust in them (Ruef \& Lounsbury, 2007). The sociological explanation regarding entrepreneurship is very helpful in creating a frame of young entrepreneur's success in maintaining their initial business, among others: because the entrepreneur strives to succeed in: (a) transitioning themselves to engage in entrepreneurship; (b) the entrepreneurship process of the business sector they run; and (c) forming an entrepreneurship structure of the business activities they have been running.

The three categorization of an entrepreneur's success stages will be much better understood when coupled with the young entrepreneurs' three basis of action identity (Rahmatiah, Wiroto, \& Taan, 2017). The transition stage into entrepreneurship is a period wherein youths come to a realization of the various life events they have, personally and collectively, experienced and then utilized as resources to develop their self potential as an entrepreneur and initiate a commitment to achieve their dreams (young entrepreneurs' first basis of action identity). A number of literatures strengthening the fact that youths' success in the transition to entrepreneurship are those stating that the human capital element is very crucial to the business founder's capability in maintaining business continuity, such as their young age and being from a minor group that faces more risks than other entrepreneurs (Boyer \& Blazy, 2014), experiences of being involved in similar industry and business sector (Gartner, Starr, \& Bhat, 1999; Englis, Ratinho, Englis \& Harms, 2010; Mishra, 2005; Boyer \& Blazy, 2014), formal education graduate (Dencker, Guber, \& Shah, 2009; Mishra, 2005). Innovation, work experience, and entrepreneurial network do not have much influence in the survival of one's 
business (Englis, Ratinho, Englis, \& Harms, 2010; Boyer \& Blazy, 2014). Of no less significance is an article written by Jaroslaw Korpysa, who emphasized that entrepreneurial zeal or enthusiasm to conduct business is very much determined by the support of family and friends, source of funding for establishing the initial business, and market conditions (Korpysa, 2019).

The entrepreneurship process is a stage in which young entrepreneurs come to realize that their commitment to achieve their dreams relates to better changes in human welfare, thus they will constantly innovate and design business plans and models when they establish, maintain, and develop their business (young entrepreneurs' second basis of action identity). A number of literatures reinforcing the fact that young entrepreneurs' success in the entrepreneurship process, among others, relate to healthy financial condition in the company that is most vital in business continuity, such as the availability of a financial management system with levels of authority in the use of money and arrangement of business income (Boyer \& Blazy, 2014), so that the business can have sufficient amount of money to pay for its obligations (Huyghebaert, Gaeremynck, Roodhooft, \& Van de Gucht, 2000). Healthy financial condition means that the company should be able to constantly fulfill the required raw materials and resources in order for the company to continue to generate products and services (Mishra, 2005; Coad, Frankish, Robert, and Storey, 2016). It is better to use general production components, including for raw materials, which is included as a good entrepreneurship process for business start-ups (Arichbald, Possani, \& Thomas, 2003). Denoo, Yli-Renko, \& Clarysse (2015) expound that new business continuity may also be caused by changes in business model, including paying attention to the products and services offered to the buyers, if they were to be changed in order to maintain and increase sales (Dencker, Guber, \& Shah, 2009).

The formation of an entrepreneurship structure is a stage wherein young entrepreneurs come to realize that their business must have the potential to grow and develop, and for that reason they constantly try to maintain the trust of their users, clients, and investors, and continue to enhance their business appeal (young entrepreneurs' third basis of action identity). Several businesses fail in this stage of entrepreneurship structure. The failure of SME businesses, according to Monk (2000), is mostly caused by SMEs inability to utilize essential management and business practices. SMEs frequently misdiagnose problematic areas and needs in their businesses. Subsequently, an example is provided indicating that businesses can survive because the management pays attention to quality and customer satisfaction (Cannon \& Edmonson, 2001). Such capacity can only be achieved if entrepreneurs are willing to learn (Cannon \& Edmonson, 2001; Atsan, 2016; Bennet, 2016) to improve their competitive advantage and continue to seek new businesses by establishing synergic relations with larger organizations.

\section{An outlook of young entrepreneurs in Indonesia, most of whom are in the micro sector}

Indonesia continues to experience entrepreneurship growth, yet in the wake of such progression there is the challenging capacity to maintain business, even more so to business actors who are novices in the business world when they established their initial business.

Results of company/business registration conducted by Indonesian Statistics (Badan Pusat Statistik - BPS) in the 2016 Economic Census (BPS, 2016) provided data that Indonesia experienced an increase in business between 2006 - 2016, as much as $17.51 \%$ (from 22.73 million to 26.71 million businesses). The amount of businesses in 2016 was dominated by small and micro enterprises (SMEs) numbering at 26.26 million businesses (98.33\%). SMEs absorbed as much as $76.28 \%$ of employment with the largest portion found in three business fields: first, retail and wholesale trade; automobile and motorcycle maintenance and repair $(28.45 \%)$; 
second, manufacturing industry (13.29\%); and third, accommodation and food and beverages provision $(11.09 \%)$.

The 2016 Indonesian Youth Statistics issued by BPS indicates that youths were mostly employed in the following top four types of employment: as manual labor and cleaning personnel, as services and sales staff in shops and traditional markets, as labor in agriculture and animal husbandry, and as laborers in manufacturing and handicrafts. Most youths worked in these three business sectors: trade, restaurant, and accommodation; agriculture; and services. This establishes a strong assumption that youths largely work in SME sectors.

The Indonesian youth population in 2016 was 62.06 million, wherein 10.87 million of them (17.53\% of the total Indonesian youth population or $4.2 \%$ of the 257.9 million Indonesian population) were young business owners, they might have conducted their own business, they might have been assisted by unpaid labor or assisted by permanent/paid labor (this data was obtained by sorting out the 2016 Indonesian Youth Statistics). The majority of young business actors in Indonesia were 25-30 years of age and graduated from middle and high schools. based on this data we can assume that young entrepreneurs on average were entrepreneurs in SME sector with low level of education. On page 75-76 in the 2016 Indonesian Youth Statistics, BPS presents their view that the low percentage of young entrepreneurs was due to the lack in youths' capacity to innovate and create, as well as their lack of courage in taking risks, resulting in their being dependent on working for others to achieve their future aspirations. This also shows the youths' low level of entrepreneurship spirit produced by the prevailing formal basic education.

The rise in the number of entrepreneurs in Indonesia does not necessarily mean increased prosperity for the entire Indonesian population. Given that there is no clear data on the rise and fall of small and micro enterprises in Indonesia, the quantity of new and surviving SMEs is, thus, beyond our understanding. The above data merely reinforce our interest, because the number of surviving small and micro enterprises was at more than $98 \%$ despite the entrepreneurs having minimum level of education and knowledge. This means that there is a possibility that these business actors had undertaken various natural processes to continue their efforts of becoming an entrepreneur.

\section{Research methodology}

This study employed the qualitative research method as a logical consequence of utilizing Margaret Archer's morphogenetic theory which puts great emphasis on social processes and qualitative changes. This study did not use the entire structure-agency-culture relation as it only emphasizes the agency element, i.e. the entrepreneurs' experiences in their relations with social and culture structures (ideas, beliefs, values, and actions of the entrepreneurs) that serve as a reference in examining the continuity of their current business. Consequentially, this study employed the narrative research method on six entrepreneur respondents residing in Gorontalo Municipality and analyzed their experiences in establishing, maintaining, and developing their business. The six entrepreneurs interviewed were: RA, owner of a furniture store (with 5 existing branches) and a side business of selling used cars; SM, owner of a mobile phone shop; YH, owner of a shop that sells cakes and biscuits known as one of Gorontalo's specialties and also owner of 6 mini market outlets; JT, owner of a drugstore and health clinic; AL, boutique owner and trend setter of Karawo (apparels made from Gorontalo traditional handcrafted cloth); and NB, owner of a restaurant serving local Gorontalo dishes who had represented Gorontalo in a national culinary competition of local Indonesian dishes in 2017. Aside from NB, the age of the five respondents could no longer be categorized as young, they did, however, begin their business at a young age (below 30). 
This study does not only intend to show the life journey of entrepreneurs and their businesses, but - by employing the narrative research method (Czarniawska, 2004) - it also intends to gain a holistic understanding of their life by arranging the narratives of their experiences in order to perceive their social actions of transforming their experiences in confronting highly unpredictable circumstances, even their failures, into facts that these are significant achievements in their life as an entrepreneur. Bloom (1996) via Merriam (2002) categorized the function of personal narratives as data, social criticism, and deconstructionthe narratives made from in-depth interviews function as data: materials for constructing an understanding on the transition of a young individual into an entrepreneur, which subsequently will be beneficial as a critical review and deconstructive instrument on the concept of young entrepreneur's success.

The research instrument employed was the interview guideline developed based on the concept of the four dimensions of Indonesian young entrepreneurs' identity (Rahmatiah, Wiroto $\&$ Taan, 2017). Analyses on the narratives made from the in-depth interviews of the six entrepreneurs produced a number of themes: (1) experience and life values; (2) background of education, employment, and replicating developed businesses; (3) principles for surviving as an entrepreneur; (4) values that excel in their business; (5) means to maintain company advantage, profit; (6) principles for maintaining and developing business; (7) knowledge and ideas in initial business establishment; (8) key components and preparations in starting a business; (9) definition of entrepreneurship; (10) system and action in managing and developing businesses; (11) utilization of social networks (that are already in place and those intentionally made) for company's interests; and (12) investment development planning. In this study, narratives under themes (1), (2), (7) and (8) were used as data to construct an understanding about the respondents' early experience when they decided to pursue entrepreneurship, whereas narratives under themes (3), (4), (5) and (6) were used as data to construct an understanding about their experience in running their initial business. In the discussion section, a model illustrating the construction of young entrepreneurs' achievements relevant to their current business continuity is presented.

\section{Study results}

\section{Youths' experiences in their transition to becoming an entrepreneur}

The transition to becoming an entrepreneur can be formed by several indicators, among others: experience and life values; background of education, employment, and replicating developed businesses; knowledge and ideas in initial business establishment; key components and preparations in starting a business. These indicators are a result of the attempt at generalizing the responses given from the conducted interviews. The table below exhibits the construction of understanding concerning the interviews with the six entrepreneur respondents within the scope of the four indicators above in order to acquire an illustration of what circumstances the youths were under when transitioning into an entrepreneur in the sociological context.

The transition conditions that youths go through to become an entrepreneur are, in fact, not so easy to understand simply. If we want to understand how an entrepreneur is able to acquire information and resources for business, then the responses provided in the table above show us that it is the fact that they never stop and wait to strive for what they need and want. The respondents above focused their attention to take any necessary measures to achieve their needs and aspirations, and their efforts had affected them to become selective of the social capital they could access with the knowledge they have. Information and resources became 
available and were activated when they did something that had positive influence on the social capital that provided the said information and resources.

Table 1. A construction of understanding based on respondents' narratives about their initial experience when deciding to become an entrepreneur

\begin{tabular}{|c|c|c|}
\hline \multirow[b]{2}{*}{ Initials } & \multicolumn{2}{|c|}{ Transition Conditions } \\
\hline & $\begin{array}{l}\text { Experiences Relating to Measures Taken } \\
\text { to Acquire Entrepreneurial Resources }\end{array}$ & $\begin{array}{l}\text { Experiences Relating to Measures Taken } \\
\text { to Acquire Information for } \\
\text { Entrepreneurial Purposes }\end{array}$ \\
\hline YH & $\begin{array}{l}\text { Rational thinking brought } \mathrm{YH} \text { to } \\
\text { understand that business resources do not } \\
\text { only come from family and close friends, } \\
\text { but they are also available via any } \\
\text { relations, among others: sellers of } \\
\text { trending products so that cheaper goods } \\
\text { can be purchased, owners of unused } \\
\text { business space, and friends you can } \\
\text { collaborate with to increase business } \\
\text { capital. }\end{array}$ & $\begin{array}{l}\text { Lessons on thinking rationally taught by } \\
\text { YH's father have always guided YH to } \\
\text { keep surviving despite being under } \\
\text { difficult conditions, such as: establishing } \\
\text { a simple trading business while } \\
\text { simultaneously seeking business } \\
\text { knowhow directly from famous business } \\
\text { players, so that a more complex business } \\
\text { can be established with a strong business } \\
\text { mentality and objective considerations of } \\
\text { the shortcomings and losses experienced } \\
\text { in the previous businesses-so that more } \\
\text { attention to detail can be afforded in } \\
\text { creating new business ventures capable of } \\
\text { capturing huge opportunities available in } \\
\text { the market. }\end{array}$ \\
\hline RA & $\begin{array}{l}\text { RA inherited a furniture store and gold } \\
\text { jewelry business from his/her parents. } \\
\text { RA's experience in securing capital to } \\
\text { open up his/her own business is by } \\
\text { collecting the readily available resources } \\
\text { and supplemented with funding from the } \\
\text { bank. }\end{array}$ & $\begin{array}{l}\text { The role of RA's father in his/her } \\
\text { upbringing by making him/her a punctual } \\
\text { person, having to manage business and } \\
\text { make financial reports since she/he was } \\
\text { little had led her/him to become an } \\
\text { entrepreneur who conducts meticulous } \\
\text { assessments before taking measures to } \\
\text { open new business ventures, which is } \\
\text { done by direct learning from business } \\
\text { actors and via the internet, to determine a } \\
\text { strategic business location, and to conduct } \\
\text { various sales strategies. }\end{array}$ \\
\hline SM & $\begin{array}{l}\text { SM's experience as a marketing staff at a } \\
\text { car sales company had led him/her to gain } \\
\text { skills and relations to establish initial trust } \\
\text { from the family who assisted him/her in } \\
\text { obtaining the capital and location } \\
\text { necessary to build his/her first business, } \\
\text { and he/she also earned trust from a large } \\
\text { supplier to provide him/her with mobile } \\
\text { phone products using very little capital. }\end{array}$ & $\begin{array}{l}\text { He/she acquired information by } \\
\text { understanding business opportunities in } \\
\text { sales of mobile phones that was } \\
\text { developing in big cities and then thought } \\
\text { about the potential of developing it in } \\
\text { his/her own city. }\end{array}$ \\
\hline $\mathrm{AL}$ & $\begin{array}{l}\text { As a civil servant-cum-lecturer in } \\
\text { Gorontalo Municipality, AL has his/her } \\
\text { own small business capital to start making } \\
\text { innovative Karawo products and } \\
\text { collaborate with local Karawo seamstress } \\
\text { and designers. }\end{array}$ & $\begin{array}{l}\text { AL's hobby in fashion, admiration to } \\
\text { famous batik designers, and } \\
\text { encouragement from numerous friends in } \\
\text { high society had ultimately led to the } \\
\text { opportunity and motivation of creating an } \\
\text { innovation in Gorontalo traditional } \\
\text { apparel called "Karawo". }\end{array}$ \\
\hline
\end{tabular}




\begin{tabular}{|c|c|c|}
\hline JT & $\begin{array}{l}\text { As a civil servant, JT was able to start her } \\
\text { business by borrowing money from the } \\
\text { bank, and being of Chinese descent there } \\
\text { is a strong culture of mutual help provided } \\
\text { for family members who want to develop } \\
\text { themselves further, hence she received } \\
\text { financial assistance from her uncle and } \\
\text { aunt, her husband also sacrificed his field } \\
\text { of expertise by becoming directly } \\
\text { involved in JT's business, and locals are } \\
\text { very loyal to her. }\end{array}$ & $\begin{array}{l}\text { JT is accustomed to working hard since } \\
\text { she was little by helping her widowed } \\
\text { mother sell goods in order to meet their } \\
\text { family's needs, this had then driven her to } \\
\text { excel in her education and work, which } \\
\text { further helped create ideas for her } \\
\text { business ventures and also in establishing } \\
\text { various businesses and their management } \\
\text { strategy. }\end{array}$ \\
\hline NB & $\begin{array}{l}\text { Without any support from NB's parents, } \\
\text { after finishing university, NB saved } \\
\text { money for three years by engaging in a } \\
\text { small catering business, and eventually } \\
\text { decided to open a restaurant using the } \\
\text { savings he/she collected after having } \\
\text { failed in the civil servant selection test. }\end{array}$ & $\begin{array}{l}\text { NB's cooking hobby and encouragement } \\
\text { from university friends, lecturers, his/her } \\
\text { aunt, and extensive relationship with } \\
\text { culinary enthusiasts who are mostly of } \\
\text { high social background had encouraged } \\
\text { her/him to start a small culinary business } \\
\text { that then developed into a restaurant } \\
\text { business. }\end{array}$ \\
\hline
\end{tabular}

The study results in this section have led to expanding the H-2 hypothesis: Youth's ability in dealing with various conditions when deciding to become an entrepreneur is determined by their ability to utilize their social relationship background and their business knowledge that can be used to gain resources and information for starting a business.

\section{Youths' experiences during the entrepreneurship process}

The data constructed in this section relates to measures youths had taken by being committed as an entrepreneur and they constantly endeavored to generate profit and form their entrepreneurial identity throughout the journey of the entrepreneurship process. The entrepreneurship process is constructed by exploring these four indicators: values that excel in their initial business; means to maintain advantage, profit and avoid losing in business competition; life principles for surviving as an entrepreneur; and principles for maintaining and developing business. The table below shows the construction of understanding concerning the interviews with the six entrepreneur respondents within the scope of the four indicators above in order to acquire an illustration of what early entrepreneurship process conditions did the young entrepreneurs experience in the sociological context.

The construction of understanding on the experiences of youths in running their initial business is, in fact, rather varied. All the entrepreneurs have different types of business, yet it is very clear that once their business started operating and they had to focus in running it properly, then they needed to deal with issues of creating innovations and having much clearer business plan. The construction of understanding in the above table shows that the conditions of entrepreneurial process that our entrepreneur respondents experienced may be classified into three motivations: the process of maintaining their business from collapsing; the process of maintaining a good system of business operation recognized by the public; and the process of developing excellent products and brand acknowledged by the public. 
Table 2. A construction of understanding based on respondents' narratives about their experience in the process of running their initial business

\begin{tabular}{|c|c|}
\hline & Proces \\
\hline Initials & $\begin{array}{l}\text { Experiences Relating to Measures Taken to } \\
\text { Maintain Profit and Business Continuity }\end{array}$ \\
\hline $\mathrm{YH}$ & $\begin{array}{l}\text { Profit and business continuity follow the } \\
\text { entrepreneur's success in building the business, } \\
\text { given that: the product is in constant demand by } \\
\text { the market; product quality is maintained; the } \\
\text { product has added value distinguishing it from } \\
\text { competitors' products; always strive to get } \\
\text { close to the community; establish a business } \\
\text { system so that finance and human resource are } \\
\text { properly managed. }\end{array}$ \\
\hline
\end{tabular}

RA Profit and business continuity are acquired and maintained through sales and product innovations. Product innovation is the efforts made to create products that draw the market's interest and possess high functionality resulting in high sales value which leads to larger profitability. Sales innovation is the means of surviving amidst strong competition by offering the best price for large product quantity to certain customers.

\begin{tabular}{ll}
\hline SM & $\begin{array}{l}\text { Profit and business continuity is very dependent } \\
\text { on the entrepreneur's ability to maintain trust in }\end{array}$
\end{tabular} supplying their product by using various sales strategies so that it continues to be sold in the market well-above the production price, particularly by maintaining the customers' loyalty to the store.

AL Substantial profit and business continuity can be obtained faster and more definite when you create a product and develop a brand that is favored by the public, that has more exclusive results, limited quantity, and difficult to imitate by other players of similar products available in the market.

JT Profit and business continuity are significantly determined by one's ability in financial management to increase the various goods and services available in their business by providing good quality of service and appropriate price, complemented with appealing customer service.

NB Profit and business continuity will always be acquired given that the financial management is properly carried out, be frugal, and maintain service quality and product excellence so that customers will continue to return.
Experiences Relating to Measures Taken to Form

Entrepreneurial Identity within Their Self

Entrepreneur is a social status relating to values of

working properly and nicely in managing business.

Properly means: focus to maintain: organizational

work system, product advantage in the market (quality and sales), and customer service. Nicely means: socialize with successful business actors to belief that one's own business is successful as well, always be capable of convincing others regarding one's own product advantage, and be capable of maintaining good relations with all contacts and competitors.

Entrepreneurs are people who own businesses and direct means of sales and purchases for the product(s) they own, they manage business finance properly, have harmonious relations with their employees, able to provide customer satisfaction, and keep maintaining the trust of business partners, all this is carried out in order to enjoy life from the fruits of their labor without having to be controlled by others.

Entrepreneurs are people who work really hard to succeed in the business they established, and they are capable of optimizing capital to restore failed businesses to get back up and running, so that they do not lose their business partners' trust, if they do have to close down a business, they should be able to explain logically and rationally from the perspective of market conditions instead of their managerial weaknesses.

Entrepreneurs are people capable of leading a team to create something of high value by confronting various substantial obstacles with the goal of creating a famous trademark loved by the public.

Entrepreneurs are people adept at choosing businesses and controlling businesses they have established, and they always exercise introspection to improve the shortcomings in their businesses, which is driven by the awareness that their businesses were developed through hard work and they have provided huge benefits to themselves, their family, and many others.

Entrepreneurs are people who establish businesses and truly master the production process, they are also capable of controlling their emotion well, so that every challenge in their businesses can be surpassed, particularly involving customer satisfaction. 
The construction of understanding based on the business experiences of RA and JT describes that entrepreneurial motivation is a process of maintaining a good publicly recognized entrepreneurial system. As JT stated, 'there may be one (business) that has achieved success, but not necessarily one hundred percent successful. I mean, when we do business, when the business has several branch stores then it's considered successful, but I was afraid, because the manager might not work optimally, so I would directly manage it again, this is the problem'. RA also provided similar emphasis, "(we should) at least persevere and try not to go down, enduring the current condition is enough, rather than falling when trying to chase after larger profit. So, it's better for us to persevere, that is enough, that's my parents' lesson'.

Entrepreneurial motivation as a process to maintain business from collapsing can be observed in the construction of understanding from the experiences of SM and NB, which implies that there will always be uncontrollable conditions despite their business being managed directly by themselves. As NB said, 'I haven't found my true self, which leads people to believe that my cooking is of value. Sometimes, many still complained with the taste of the food, for instance when I'm tired I may have forgotten to put some spices, and usually when my employees put them in it will be different'. This is in line with the explanation from SM, 'Our competitors all have strong capital, while ours is just enough, it will be very difficult to go against them. Of course everything depends on capital. So, we have to find ways to persevere'.

$\mathrm{AL}$ and $\mathrm{YH}$ are two entrepreneurs whose construction of understanding concerning the initial business process is the motivation to provide excellent product and publicly acknowledged brand, although great struggle is required to create a good entrepreneurial system. As YH stated, 'I will become a big entrepreneur, but what's my business, what's the product, I don't know yet. Will pia (sweet pastry) be a big business, or will I develop my parents' hotel business, I also don't know. I need only to instill in my mind that I can be a winner, that I am a big entrepreneur'. AL also has an opinion with similar understanding, 'I want to make Karawo style apparels up to the point that people would appreciate it by saying "wow!", "so cool!", "this is just like boutique quality clothing", and in my boutique people would feel nuances unlike that of being in other Karawo shops'.

The study results in this section have led to expanding the H-3 hypothesis: youth's ability in dealing with various conditions when conducting business processes is determined by their ability to constantly gain profit, apply entrepreneurial principles and values, and keep motivated in running the businesses they own.

H-2 and H-3 hypotheses, which initially are an elaboration derived from the four dimensions of entrepreneur identity (Rahmatiah, Wiroto, and Taan, 2017), may be employed to examine the processes a young individual goes through in becoming an entrepreneur and maintaining their business. The fourth dimension of the entrepreneur identity, which is entrepreneurship implementation, remains unnecessary for use in this study due to the fact that only two informants truly possessed this identity. Additionally, it is only beneficial when applied to studies pertaining to entrepreneur informants who are motivated to develop highquality products and well-recognized brands (those who have reached the business development stage).

The results of this study have not been able to explain whether the $\mathrm{H}-1$ hypothesis is acceptable. The condition of youths when transitioning to become entrepreneurs has yet to indicate any existing correlation with their business continuity, in other words, it is merely limited to starting a business. Subsequently, we will discuss how the transition of youths to become entrepreneurs can reinforce their motivation to maintain business continuity. 


\section{Discussion}

\section{Commitment as an entrepreneur and motivation in maintaining business continuity}

The positive relationship between efforts to achieve youths' needs and desires, easily accessible social capital, and agency action in the form of positive information and resources utilization that influences motivation and finance at the early stages of business initiation is known as the entrepreneur's commitment. It is this commitment that is referred to in the young entrepreneur's first basis of action identity, wherein youths come to realize the various life events they had, personally and collectively, experienced and use them as a source to develop their self potential as an entrepreneur and initiate a commitment to achieve their dreams. The entrepreneur's commitment links the entrepreneur's self with their social capital, explicitly via written agreement at the initial business establishment and implicitly through monitoring of the young entrepreneur's work ethic and business relations as well as the business strategy applied. The entrepreneur's commitment intensity in managing their initial business will have an impact on the opening/closing of access to new or existing social capital. Commitment also forms the youth's motivation to engage in entrepreneurship.

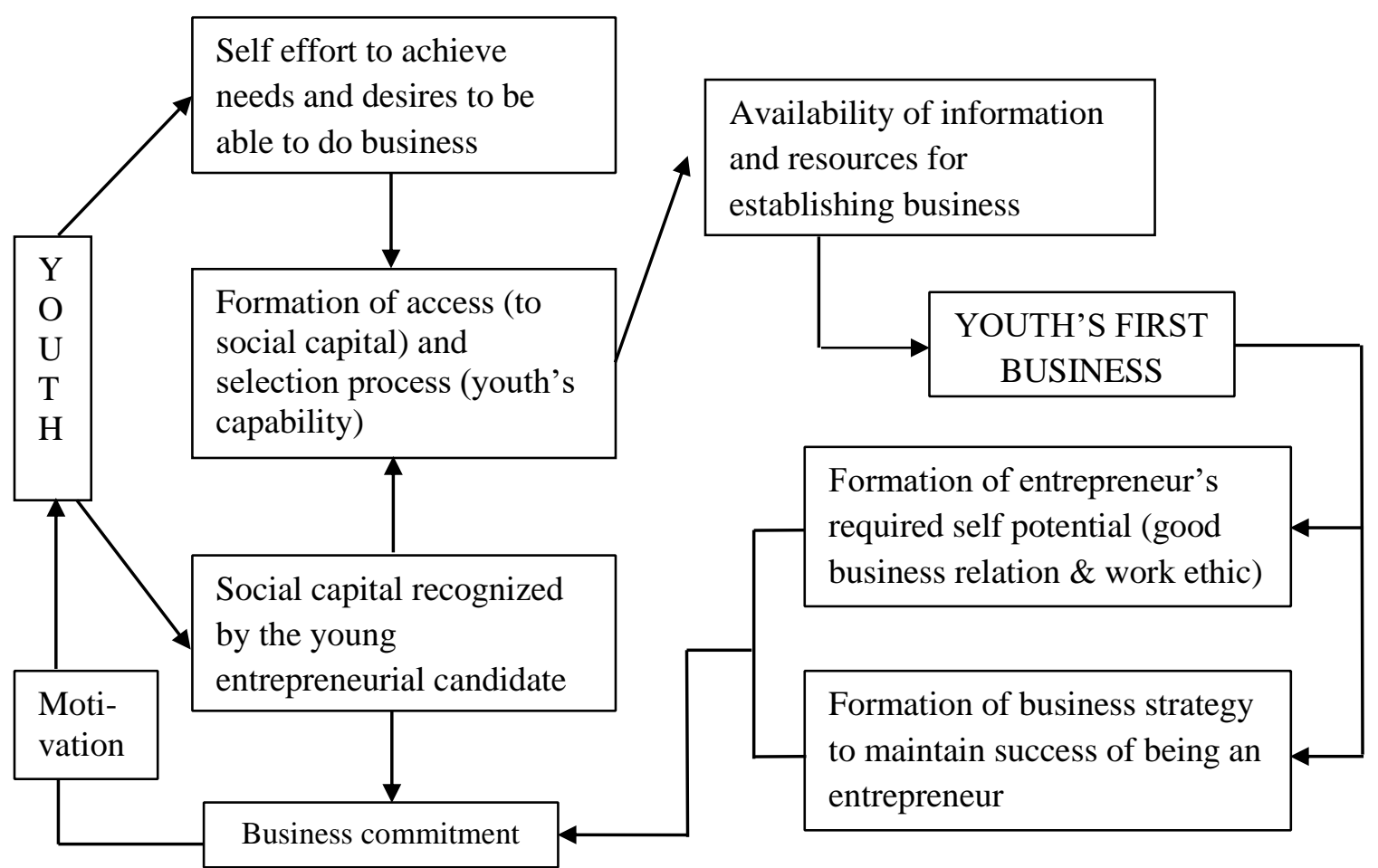

Schema 1. Business motivation and commitment as a result of youths' interaction and their businesses

The commitment of these six entrepreneurs has truly shown that their biggest concern is that there is no room for failure in their efforts of attaining the capacity to fulfill their life necessities by establishing their own business independently. However, based on the entrepreneurial process conditions above, it is obvious that their motivation of becoming independent varies. The entrepreneurs' interactions with their first business when undergoing the process of running their business have resulted in three varying motivations in maintaining the continuity of their initial business: (1) the process of maintaining business from collapsing; 
(2) the process of maintaining good entrepreneurial system recognized by the public; (3) the process of developing excellent product and brand acknowledged by the public. It is clear hat the third condition is more superior than the second and the first, while the second condition is more superior than the first. How do these processes form? Is there any relation with the conditions of transition into an entrepreneur? Since, rationally speaking, it is impossible that an entrepreneur would want their initial business having to go to the first motivation, or at least to the second condition.

To address these matters, we need to understand a clear connection between the condition of youths when transitioning to become entrepreneurs and the motivation to maintain the continuity of their initial business. Generally, we would say that these young entrepreneurs have no other choice but to maintain their business. However, upon closer examination of Table 1 above, it is quite apparent that the decision to become an entrepreneur is an open choice both to those who have capital and to those who don't. Therefore, maintaining business continuity is not merely maintaining business profitability. Maintaining business profitability only relates to the practical and natural aspects of an entrepreneur (by enhancing their managerial and business knowledge), it has yet touched upon the social aspect.

The social order that an entrepreneur experience is similar with that which people in general experience, and that is their social environment, but specifically, it is the social environment in which the entrepreneur gains social relations to obtain business knowledge and skills and to organize their managerial role as an entrepreneur. This managerial role cultivates a perception within social relations about their self that they can truly be recognized as an entrepreneur. Based on this, a young entrepreneur becomes committed so that he/she can maintain business continuity, although there are varying motivations, and this recognition is an actual form of self-reputation, which means that if the reputation is hindered, then the social relations can become weak or ruined, and this may hamper their activities in maintaining their business (destroying the practical and natural order).

This description is in line with the explanation provided by Margaret Archer on social morphogenetic relating to the emergence of personal identity in her book titled Being Human: The Problem of Agency (Archer, 2004: 253-305). The formation of personal identity shares a reciprocal relationship with the formation of social identity. Once an individual finds a way to fulfill the opportunity to live (life-chances), it means that that individual has become an agent capable of playing roles and producing creativity to continue (reproduce) or change the position of their own self or their social system through their wealth remuneration, representation, and repute. Archer wrote, "we are also persons who are concerned about our concerns: this is what commitment means" (Archer, 2004: 298), this implies that young entrepreneurs will constantly be concerned about their reputation, business company (representation), and wealth (remuneration).

This discussion has led to validating and even expanding the $\mathrm{H}-1$ hypothesis: The continuity of youth's business is determined by their ability in dealing with various conditions when deciding to become an entrepreneur and conducting the business processes, and to remain committed as an entrepreneur although there are differing motivations.

Up to this point, we have yet acquired a clear explanation as to why young entrepreneurs have differing motivations, despite all of them being committed to their role as an entrepreneur. The following discussion maintains the argument that the social relation factor can be used to explain the differences in the business operation of the young entrepreneurs in Gorontalo. 


\section{The construction of understanding the successful achievement of young entrepreneurs' initial business}

Based on Schema 1 above, the formation of motivation can be observed, if we retrace the steps, it is preceded by a formation process of access to social capital and acceptance by social capital actors of youths to acquire information and resources in the process of becoming entrepreneurs - which is formed because of the youths' efforts in fulfilling their needs and desire of becoming entrepreneurs (the formation of entrepreneurial rationality within the youths) and in getting to know social actors who have the potential to be included as their social capital. We can, thus, conclude that the condition of young entrepreneurs' business continuity is determined by the amount of efforts they spend in rationalizing their needs and desire to become an entrepreneur and the amount of social relations they have to turn into an access to social capital for the sake of operating their initial business.

Table 3. Differences in conditions of business continuity according to the efforts of entrepreneurial rationality formation and the amount of social relation types during the transition into an entrepreneur

\begin{tabular}{|c|c|c|c|}
\hline \multirow[t]{2}{*}{ Initials } & \multirow{2}{*}{$\begin{array}{l}\text { Initial Business } \\
\text { Continuity Condition }\end{array}$} & \multicolumn{2}{|l|}{ Social Conditions } \\
\hline & & $\begin{array}{l}\text { Efforts of Entrepreneurial Rationality Formation } \\
\text { within the Youths }\end{array}$ & $\begin{array}{l}\text { Amount of Social } \\
\text { Relation Types }\end{array}$ \\
\hline YH & $\begin{array}{l}\text { The process of } \\
\text { developing excellent } \\
\text { product and brand } \\
\text { acknowledged by the } \\
\text { public }\end{array}$ & $\begin{array}{l}\text { Parents' upbringing who are also entrepreneurs; } \\
\text { unemployed after graduating high school; } 1998 \\
\text { monetary crisis; business opportunity due to lack of } \\
\text { goods in the market; participated in various } \\
\text { entrepreneurship self-development training; self- } \\
\text { confidence of becoming a successful entrepreneur; } \\
\text { learnt to do business from unorganized to being } \\
\text { organized }\end{array}$ & $\begin{array}{l}\text { 5: father, } \\
\text { successful } \\
\text { entrepreneurs, a } \\
\text { faculty dean, wife, } \\
\text { competitors }\end{array}$ \\
\hline $\mathrm{AL}$ & $\begin{array}{l}\text { The process of } \\
\text { developing excellent } \\
\text { product and brand } \\
\text { acknowledged by the } \\
\text { public }\end{array}$ & $\begin{array}{l}\text { The opportunity of making exclusive Karawo } \\
\text { apparels was discovered through friends of high } \\
\text { economic status; knowledge about style and } \\
\text { fashion wear complemented by friends; Iwan } \\
\text { Tirta's success in elevating Batik to the } \\
\text { international level; natural ability to promote } \\
\text { products through work as a master of ceremony; } \\
\text { small initial capital }\end{array}$ & $\begin{array}{l}\text { 5: friends, } \\
\text { KADIN, Bank } \\
\text { Indonesia, clients } \\
\text { using his service } \\
\text { as a master of } \\
\text { ceremony, former } \\
\text { minister }\end{array}$ \\
\hline JT & $\begin{array}{l}\text { The process of } \\
\text { maintaining good } \\
\text { entrepreneurial system } \\
\text { recognized by the } \\
\text { public }\end{array}$ & $\begin{array}{l}\text { Exercises strict discipline in managing parent's } \\
\text { store since little; employment and education } \\
\text { background is associated with business developed; } \\
\text { driven by challenge to fulfill life necessities }\end{array}$ & $\begin{array}{l}\text { 5: mother, } \\
\text { husband, aunt, } \\
\text { uncle, and loyal } \\
\text { local customers, } \\
\text { doctors }\end{array}$ \\
\hline RA & $\begin{array}{l}\text { The process of } \\
\text { maintaining good } \\
\text { entrepreneurial system } \\
\text { recognized by the } \\
\text { public }\end{array}$ & $\begin{array}{l}\text { Lessons from parents who are also entrepreneurs; } \\
\text { strict discipline in managing parents' store since } \\
\text { little; all family members are entrepreneurs; ability } \\
\text { in financial management since her/his teen }\end{array}$ & $\begin{array}{l}\text { 3: father, siblings, } \\
\text { competitors }\end{array}$ \\
\hline SM & $\begin{array}{l}\text { The process of } \\
\text { maintaining business } \\
\text { from collapsing }\end{array}$ & $\begin{array}{l}\text { Noticing that huge opportunity is still available; } \\
\text { place for business is available }\end{array}$ & $\begin{array}{l}\text { 2: distributors, } \\
\text { wife }\end{array}$ \\
\hline NB & $\begin{array}{l}\text { The process of } \\
\text { maintaining business } \\
\text { from collapsing }\end{array}$ & $\begin{array}{l}\text { Talented in cooking local dishes; positive support } \\
\text { from friends to open up a business with the talent } \\
\text { he/she has; savings is available to start the business } \\
\text { that was initiated in college }\end{array}$ & 2: friends, aunt \\
\hline
\end{tabular}


Based on Table 3 above, we can observe that YH and AL's business continuity performed better than the remaining four, and they take the most efforts in forming entrepreneurial rationality within themselves, which happened to them deliberately (due to the gradual development of their internal situation) or incidentally through unexpected incidences (due to the dynamic external situation). The amount of social relation types they had used as social capital was in fact more than the other young entrepreneurs. JT and RA, despite having nearly similar amount of social relations, the formation of their rationality was only driven by the gradual development of their internal situation. SM and NB's entrepreneurial rationality was only formed through the gradual development of their internal situation and the amount of their social relations was not significant enough and too specific.

Based on the discussion, it can be concluded that in order to address their biggest concern (i.e. must not fail in the effort of gaining the capability to fulfill life necessities by independently setting up a business), young entrepreneurs use all their potentials to be able to ascribe meaning to various social and personal life events as a self-reflection power to become an entrepreneur that influence their ability to: (1) make subjective assessment in using social relations to develop social capital for accessing resources; and (2) make profit and loss calculation in choosing the type and form of business that will be established. The youths' power of reflection will determine the strength of entrepreneurial commitment when their first business is initiated and determine the motivational strength to run the business and develop the youths' entrepreneurial identity. The motivation of young entrepreneurs illustrates their confidence in describing the success of their business.

\section{Conclusion}

The transition of youths into entrepreneurs is a significant social phenomenon, in both quantity and quality. This research puts emphasis on the quality aspect, wherein becoming an entrepreneur is not only challenging in terms of business management. This research substantiates that the formation of young entrepreneurs' motivation is a significant social process and it demands a high level of awareness to understand and ascribe meaning to the various social structures and cultural system that form their great concern throughout the process of their personal life journey. This provides practical implications for entrepreneurs to have greater commitment as an entrepreneur, not only to themselves and their company, but also to the social system. Entrepreneurs should more vigourously promote the benefit of their business through various social relations, hence resulting in greater motivation to maintain business continuity.

The conclusion from the above discussion shows that this study has extensively opened sociology's (theoretical implications) attention to the young entrepreneur phenomenon that relates to the social morphogenetic meta-theory, particularly entrepreneurs as social agents. Young entrepreneurs are social agents, given their reflective capacity, they are thus in line with the definition of social agents, which is an active and reflective individual, or those who have "the properties and powers to monitor their own lives, to mediate structural and cultural properties of society and thus to contribute to societal reproduction or transformation" (Brock, Carrigan \& Scambler, 2017). Young entrepreneurs' achievement of success is constructed by the actions of youth agency in employing their various social conditions and utilizing their social relations to maintain business continuity.

This study has led to the following proposition: more dynamic social conditions and more social relations result in more successful business continuity for it is driven by more superior motivation of young entrepreneurs; conversely, if social conditions are merely formed by internal conditions and fewer social relations, then youths' motivation to continue their 
business is low. This proposition should be verified using a statistical test via a quantitative study. Therefore, this research also criticizes the narrow perspective that becoming an entrepreneur is merely a matter of interest, expertise, and individual courage, which nearly lacks explanation on external influences such as social reality and social relations.

We suggest that sociologists use the morphogenetic approach in studying social relations and motivation of young entrepreneurs. This study is undoubtedly very limited to the social interactions of youths and the businesses they established, but at the very least, it has opened up a new insight wherein the habit of engaging in family business indicates a natural collaboration among family members to do business. Thereby, we suggest that the subsequent sociological study should pertain to entrepreneurship to discuss themes of collaborative family, as a step to implement the structure and agency theory in creating social agents that the public requires.

\section{References}

Archer, M. S. (2004). Being human: The Problem of Agency. Cambridge: Cambridge University Press.

Atsan, N. (2016). Failure Experiences of Entrepreneurs: Causes and Learning Outcomes. In Mehtap Özşahin (Ed.). Procedia - Social and Behavioral Sciences 235: Proceedings of the 12th International Strategic Management Conference, ISMC 2016 (pp. 435-442). Antalya, Turkey: Elsevier.

Bennet, R. (2016). Factors contributing to the early failure of small new charity start-ups. Journal of Small Business and Enterprise Development, 23(2), 333 - 348. doi: 10.1108/JSBED-11-2013-0173.

Bloom, L. R. (1996). Stories of One's Own: Nonunitary Subjectivity in Narrative Representation. In S. B. Merriam (Ed.), Qualitative Research in Practice: Examples for Discussion and Analysis. (pp. 289-313). San Fransisco, CA: Jossey-Bass

Boyer, T., \& Blazy, R. (2014). Born to be alive? The survival of innovative and non-innovative French micro-start-ups. Small Business Economics, 42(4), 669-683. doi: 10.1007/s11187-013-9522-8.

Badan Pusat Statistik. (2016). Hasil Pendaftaran (Listing) Usaha/Perusahaan Sensus Ekonomi 2016. Berita Resmi Statistik (No. 50/4/Th. XX). Retrieved March 3, 2018, from https://se2016.bps.go.id/Lanjutan/files/brs/BRS_hasillisting.pdf.

Badan Pusat Statistik. (2016). Statistik Pemuda Indonesia 2016. Retrieved March 3, 2018 from https://www.bps.go.id/publication/2017/11/03/5cdcfabd0f6fca476cb5 48e6/statistikpemuda-indonesia-2016.html.

Brock, T., Carrigan, M, \& Scambler, G. (2017). Structure, Culture, and Agency: Selected Papers of Margaret Archer. Oxon and New York: Routledge.

Cannon, M. D., \& Edmondson, A. C. (2001). Confronting failure: antecedents and consequences of shared beliefs about failure in organizational work groups. Journal of Organizational Behaviour. 22, 161-177. doi: 10.1002/job.85.

Coad, A., Frankish, J. S., Roberts, R. G., \& Storey, D. J. (2016). Predicting new venture survival and growth: Does the fog lift? Small Business Economics, 47(1), 217-241. doi: 10.1007/s11187-016-9713-1.

Collins, R. (1980). Weber's Last Theory of Capitalism: A Systematization. American Sociological Review, 45(6), 925-942. doi: 10.2307/2094910.

Czarniawska, B. (2004). Narratives in Social Science Research. London, Thousand Oaks, and New Delhi: SAGE Publications. 
Dencker, J. C., Gruber M., \& Shah, S. K. (2009). Pre-Entry Knowledge, Learning, and the Survival of New Firms. Organization Science 20(3), 516-537. doi: 10.1287/orsc. 1080.0387 .

Denoo, L., Yli-Renko, H., \& Clarysse, B. (2015). The impact of business model change on new ventures' survival. Frontiers of Entrepreneurship Research, 35(9), Article 9. Retrieved from http://digitalknowledge.babson.edu/fer/vol35/iss9/9.

Englis, P. D., Ratinho, T., Englis, B. G., \& Harms, R. (2010). Extensiveness of Business Planning and Firm Survival: an Examination into the Drivers of Success and Survival for Knowledge Intensive Start-up Firms (Interactive paper). Frontiers of Entrepreneurship Research, 30(12), Article 20. Retrieved from http://digitalknowledge.babson.edu/fer/vol30/iss12/20/.

Furlong, A and Cartmel, F. (2007). Young People and Social Change: New Perspectives. Berkshire: Open University Press.

Grilli, L. (2010). When the going gets tough, do the tough get going? The pre-entry work experience of founders and high-tech start-up survival during an industry crisis. International Small Business Journal, 29(6), 626-647. doi:10.1177/0266242610372845.

Gartner, W. B., Starr, J., \& Bhat, S. (1999). Predicting new venture survival: an analysis of "anatomy of a start-up." Cases from inc. Magazine. Journal of Business Venturing, 14(2), 215-232. doi: 10.1016/S0883-9026(97)00063-3.

Huyghebaert, N., Gaeremynck, A., Roodhooft, F., \& Van de Gucht, L. M. (2000). New firm survival: start-up characteristics. Journal of Business Finance \& Accounting, 27(5) \& (6), 627-651. doi: 10.1111/1468-5957.00328.

Korpysa, J. (2019). Entrepreneurial Intentions of Students as the Future Business Leaders. In W. Strielkowski (Ed.) Sustainable Leadership for Entrepreneurs and Academics: 2018 Prague Institute for Qualification Enhancement (PRIZK) International Conference "Entrepreneurial and Sustainable Academic Leadership" (ESAL2018) (p. 315), Prague.

Lewin, P. (2012, June). What Do We Know For Certain About Uncertainty? Issues of economic risk and uncertainty. The Legatum Institute Charles Street Symposium, Mayfair, London.

Lippman, S., Davis, A., \& Aldrich, H. E. (2005). Entrepreneurship and Inequality. In L. A. Keister (Ed.), Research in the Sociology of Work (15): Entrepreneurship (pp. 3-31). doi: 10.1016/S0277-2833(05)15002-X

Mishra, A. (2005). Entrepreneurial Motivations in Start-up and Survival of Micro- and Small Enterprises in the Rural Non-Farm Economy. Journal of Small Business and Entrepreneurship, 18(3), 289-326. doi: 10.1080/08276331.2005.10593345.

Mole, K. \& Mole, M. (2010). Entrepreneurship as the Structuration of Individual and Opportunity: A Response Using A Critical Realist Perspective: Comment on Sarason, Dean and Dillard. Journal of Business Venturing, 25 (2). 230-237. Doi: 10.1016/j.jbusvent.2008.06.002.

Monk, R. (2000). Why small businesses fail. CMA Management, 74(6), 12-13. Retrieved February 18, 2018, from https://e-resources.perpusnas.go.id:2057/ docview/197767164? accountid=25704.

Rahmatiah, Wiroto, D. W., \& Taan, H. (2017). A Conceptual Framework in the Formation of Young Entrepreneurs in Indonesia. Junal Ilmu Sosial dan Ilmu Politik, 21 (2). 102-116. doi: $10.22146 /$ jsp. 30435 .

Ruef, M., \& Lounsbury, M. (2007). Introduction: The Sociology of Entrepreneurship. In M. Ruef and M. Lounsbury (Eds.), Research in the Sociology of Organizations (25): The Sociology of Entrepreneurship (pp. 1-29). doi: 10.1016/S0733-558X(06)25001-8. 
Thomas, L. C., Possani, E., \& Archibald, T. W. (2003). How useful is commonality? Inventory and production decisions to maximize survival probability in start-ups. IMA Journal of Management Mathematics, 14(4), 305-320. doi:10.1093/imaman/14.4.305.

Williams, C. C., \& Nadin, S. (2010). Entrepreneurship and the informal economy: An overview. Journal of Developmental Entrepreneurship, 15(4), 361-378. doi:10.2139/ssrn.2290544.

Williams, C. C., \& Gurtoo, A. (2012). Evaluating competing theories of street entrepreneurship: some lessons from a study of street vendors in Bangalore, India. International Entrepreneurship and Management Journal, 8, 391-409. doi:10.1007/s11365-0120227-2.

Wiroto, D. W. (2016). Kapital sosial dan kepemimpinan dalam pengembangan kompetensi usaha mikro dan kecil di era MEA: sebuah tinjauan konseptual ringkas. In M. Ilyas, R. Junaid, H. Asri. (Eds.). Kesiapan Daerah Menghadapi Masyarakat Ekonomi ASEAN (MEA): Proceedings of Universitas Cokroaminoto 2016 National Seminar (pp.591601). Palopo, Sulawesi Selatan. 